\title{
Formation of carcinogenic chromosomal rearrangements in human thyroid cells after induction of double-strand DNA breaks by restriction endonucleases
}

\author{
Viktoria Evdokimova, Manoj Gandhi, Jayanagendra Rayapureddi', \\ James $R$ Stringer ${ }^{2}$ and Yuri E Nikiforov
}

Department of Pathology, University of Pittsburgh, 200 Lothrop Street, PUH, Room C-606, Pittsburgh, Pennsylvania 15213, USA Departments of ${ }^{1}$ Pathology and ${ }^{2}$ Molecular Genetics, University of Cincinnati, Cincinnati, Ohio 45221, USA

(Correspondence should be addressed to Y E Nikiforov; Email: nikiforovye@upmc.edu)

\begin{abstract}
lonizing radiation (IR) exposure increases the risk of thyroid cancer and other cancer types. Chromosomal rearrangements, such as RET/PTC, are characteristic features of radiationassociated thyroid cancer and can be induced by radiation in vitro. IR causes double-strand breaks (DSBs), suggesting that such damage leads to RET/PTC, but the rearrangement mechanism has not been established. To study the mechanism, we explored the possibility of inducing RET/PTC by electroporation of restriction endonucleases (REs) into HTori-3 human thyroid cells. We used five REs, which induced DSB in a dose-dependent manner similar to that seen with IR. Although all but one RE caused DSB in one or more of the three genes involved in $R E T / P T C$, rearrangement was detected only in cells electroporated with either Pvull (25 and $100 \mathrm{U}$ ) or Stul (100 and $250 \mathrm{U}$ ). The predominant rearrangement type was RET/PTC3, which is characteristic of human thyroid cancer arising early after Chernobyl-related radioactive iodine exposure. Both enzymes that produced RET/PTC had restriction sites only in one of the two fusion partner genes. Moreover, the two enzymes that produced RET/PTC had restriction sites present in clusters, which was not the case for RE that failed to induce RET/PTC. In summary, we establish a model of DSB induction by RE and report for the first time the formation of carcinogenic chromosomal rearrangements, predominantly RET/PTC3, as a result of DSB produced by RE. Our data also raise a possibility that $R E T / P T C$ rearrangement can be initiated by a complex DSB that is induced in one of the fusion partner genes.
\end{abstract}

Endocrine-Related Cancer (2012) 19 271-281

\section{Introduction}

Ionizing radiation (IR) is a well-known carcinogen linked to a variety of human cancers. One of those is thyroid cancer, which has a well-established link to the exposure to external $\gamma$ - and X-ray radiation (Schneider 1990, Ron et al. 1995, Schlumberger et al. 1999) and internal exposure to ingested I-131 (Tuttle \& Becker 2000, Cardis et al. 2005a). The risk of thyroid cancer has a linear dose response for doses $0.1-2 \mathrm{~Gy}$, with flattening of the dose-response curve at higher doses (Ron et al. 1995, Cardis et al. 2005a,b).
Over the last decade, strong evidence has been accumulated supporting the central role of chromosomal rearrangements in carcinogenesis initiated by IR (Ciampi et al. 2005, Gandhi et al. 2010). A prototypic example of such radiation-induced rearrangement is a RET/PTC rearrangement, which is highly prevalent in thyroid cancer in individuals exposed to IR (Bounacer et al. 1997, Rabes et al. 2000, Collins et al. 2002) and can be induced in thyroid cells by IR in vitro (Ito et al. 1993, Mizuno et al. 2000, Caudill et al. 2005). The two most common rearrangement types are RET/PTCl and 
RET/PTC3, in which RET is fused to either CCDC6 $(H 4)$ or the NCOA4 (ELE1) gene (Grieco et al. 1990, Santoro et al. 1994). RET/PTCl is more common after $\gamma$-radiation, whereas $R E T / P T C 3$ was the predominant type in patients exposed to I-131 after Chernobyl who developed thyroid cancer $<10$ years after exposure (Bounacer et al. 1997, Nikiforov et al. 1997, Rabes et al. 2000). In vitro, the formation of RET/PTC can be found in thyroid cells exposed to external $\gamma$-and X-ray radiation (Ito et al. 1993, Mizuno et al. 2000, Caudill et al. 2005). The findings in the human populations and in experimental models provide strong evidence for the direct role of radiation in generating RET/PTC. Understanding of the mechanisms of formation of this carcinogenic rearrangement can therefore provide important insights into the mechanisms of radiation carcinogenesis in human thyroid cells and in other cell types.

IR is known to induce various types of DNA damage, of which double-strand breaks (DSBs) are considered to be a crucial primary lesion for a variety of biological end points, including chromosomal aberrations and cell transformation (Bryant \& Riches 1989, Winegar et al. 1992). However, how exactly radiogenic DSBs lead to chromosomal aberrations remain unclear. Three basic theories have been proposed. The Breakage-and-Reunion theory postulates that chromosomal aberrations arise mainly as a result of rejoining of two DSBs located closely in space and time (two-hit event) (Savage 1998, Hlatky et al. 2002). Presumably, most rejoining events occur via nonhomologous end joining (Yates \& Morgan 1993, Rothkamm et al. 2001). An alternative, one-hit mechanism is suggested by the Molecular theory, which postulates that one radiation-induced DSB is sufficient to initiate an exchange that occurs with an undamaged DNA molecule (Chadwick \& Leenhouts 1978, Goodhead et al. 1993). The plausible mechanism for such a series of events is homologous recombination initiated by one DSB. The Exchange theory suggests that the initiation lesions are not DNA breaks induced by radiation but rather 'unstable lesions' that do not disrupt the continuity of chromosomes but can initiate exchange between two lesions (Revell 1975). Although the Breakage-and-Reunion theory remains most widely accepted, none of the three theories can adequately explain all available experimental data on the dose-effect relationship and complexity of radiation-induced aberrations (Edwards 2002). Moreover, these theories are based on the assumption that primary DNA lesions are directly induced by radiation. However, additional evidence exists that radiation can lead to chromosomal exchanges by an indirect mechanism, i.e. mediated by radiation-induced genomic instability. This possibility is supported by studies showing the occurrence of new chromosomal aberrations in subsequent generations of a cell exposed to radiation (Huang et al. 2003, Little 2003), and by a bystander effect, where aberrations are found in cells plated close to, but not in, the field of irradiation or partial irradiation of a cell cytoplasm (Ludwików et al. 2002, Morgan et al. 2002, Little et al. 2003).

In human tumors, the breakpoints of RET/PTC rearrangements typically reside within a $1.8 \mathrm{~kb}$ intron 11 of RET and in intronic sequences in CCDC6 (intron $7,1.7 \mathrm{~kb}$ ) and CCDC6 (intron 1, $53.4 \mathrm{~kb}$ ), allowing for undisturbed splicing and expression of genetic chimeras. Analysis of genomic breakpoints in RET/PTC3 rearrangements in post-Chernobyl thyroid tumors showed random distribution of the breakpoints within the introns, presence of common regions of microhomology composed of three to five nucleotides at the breaks, and minimal modification of sequences at the breakpoints (Bongarzone et al. 1997, Nikiforov et al. 1999, Klugbauer et al. 2001). We have previously reported a dose-dependent generation of RET/PTC rearrangements by $\gamma$-radiation in thyroid HTori-3 cells, which are immortalized, partially transformed cells that preserved features of thyroid differentiation (Caudill et al. 2005).

IR breaks DNA at random location, which precludes investigation of the role of any particular break in the mechanism of RET/PTC formation. By contrast, restriction endonucleases (REs), which can be introduced into mammalian cells by electroporation, cause DSBs at defined chromosomal locations (Bryant 1988, Ager et al. 1991, Obe et al. 1992). REs have been widely used to study the biological consequences of DSBs in the genome, which include the generation of chromosomal rearrangements, among other effects. A linear dose response has been reported in studies on the frequency of chromosomal aberrations induced by restriction enzymes introduced into mammalian cells (Bryant 1984, Winegar et al. 1989, Yates \& Morgan 1993).

In this study, we compared the characteristics of DSBs induced by IR and RE in thyroid cells and used $\mathrm{RE}$ induction of DSBs to study the generation of RET/PTC rearrangements in thyroid cells.

\section{Materials and methods}

\section{Cell line and culture conditions}

HTori-3 cells, which are normal human thyroid cells transfected with an origin-defective SV40 genome (Lemoine et al. 1989), were purchased from the 
European Tissue Culture Collection (Salisbury, Wiltshire, UK). They are partially transformed but retain a differentiated phenotype as indicated by the ability to accumulate iodine and produce thyroglobulin $(\mathrm{Tg})$. We have previously shown that our HTori-3 cells express both sodium/iodide symporter and $\mathrm{Tg}$ (Caudill et al. 2005). Primary cultures of human thyroid epithelial cells were established from surgically removed tissues as described previously (Nikiforova et al. 2000).

\section{Cell irradiation}

Human thyroid primary cells $\left(2 \times 10^{3}\right)$ or HTori- 3 cells were plated in a $35 \mathrm{~mm}$ plate with coverslip and $16 \mathrm{~h}$ later exposed to a single dose of $\gamma$-irradiation from cesium-137 (Gamma Cell 40 irradiator) at a dose rate of $0.58 \mathrm{~Gy} / \mathrm{min}$. Cells were exposed to $0.1,0.5,1$, and 5 Gy $\gamma$-irradiation and incubated at $37{ }^{\circ} \mathrm{C}$ for different periods, $1,2,4,6,24,48$, and $72 \mathrm{~h}$, and subjected to $\gamma \mathrm{H} 2 \mathrm{AX}(\mathrm{H} 2 \mathrm{AFX})$ immunofluorescence.

\section{Electroporation of restriction enzymes and detection of RET/PTC rearrangements}

PvuII, StuI, EcoRV, ScaI, and NruI RE (New England Bio Labs, Ipswick, MA, USA) were electroporated into human thyroid primary cells or HTori-3 cells by a previously described method (Carney \& Morgan 1999). Briefly, $2 \times 10^{6}$ cells in $800 \mu \mathrm{l}$ PBS were electroporated with different amounts of enzymes at $50 \mathrm{mC}$ charge $(400 \mathrm{~V}$ and $125 \mu \mathrm{F})$ using Gene Pulser Xcell Electroporator (Bio-Rad). For the detection of $R E T / P T C$, in each experiment, the electroporated cells were seeded in $30 \mathrm{~T} 25$ flasks $\left(6.6 \times 10^{4}\right.$ cells per flask $)$. To sustain continuous growth, cells were transferred to T75 flasks on day 5 post-electroporation and harvested on day 9. RNA was extracted from each flask using a Trizol reagent (Invitrogen) and mRNA was purified using Oligotex mRNA mini kit (Qiagen). RT-PCR with primers specific for RET/PTC1 and RET/PTC3 was performed and RET/PTC detection was achieved by Southern blot hybridization of the PCR products with ${ }^{32} \mathrm{P}$-labeled oligonucleotide probes specific for each rearrangement type as described previously (Caudill et al. 2005). Evidence of RET/PTC rearrangement in the cells from a given flask was scored as one RET/PTC event.

Electroporation efficacy for all studied enzymes was assayed by $\mathrm{\gamma H} 2 \mathrm{AX}$ immunofluorescence after $4 \mathrm{~h}$ post-electroporation. Cell survival after electroporation of each RE was evaluated $24 \mathrm{~h}$ postelectroporation by trypan blue exclusion.

\section{$\gamma \mathrm{H} 2 \mathrm{AX}$ immunofluorescence}

$\gamma \mathrm{H} 2 \mathrm{AX}$ immunofluorescence was used to confirm DSB formation after irradiation and RE electroporation of human thyroid cells as well as for DSB quantitation. Cells cultured on coverslips were fixed with $4 \%$ formaldehyde for $10 \mathrm{~min}$ followed by the permeabilization with $0.5 \%$ Triton X-100 on ice for 5 min. After washing with PBS, cells were stained with $100 \mu$ l staining solution $(20 \mathrm{mM}$ Tris, pH 7.6, $137 \mathrm{mM} \mathrm{NaCl}, 10 \%$ skimmed milk, and $0.5 \%$ Tween-20) containing antiphosphorylated histone H2AX primary antibody (Upstate Biotechnology, Buffalo, NY, USA) at 1:1000 dilution for $2 \mathrm{~h}$ at $37^{\circ} \mathrm{C}$. Coverslips were washed with PBS twice and incubated with Alexa488labeled antimouse IgG (Molecular Probes, Eugene, OR, USA) in staining solution (1:200) for $1 \mathrm{~h}$ at $37^{\circ} \mathrm{C}$. After washing with PBS, samples were counterstained with DAPI (Suzuki et al. 2006). In order to quantify the number of DSBs, $\gamma \mathrm{H} 2 \mathrm{AX}$ foci were counted in individual nucleus scanned using a Leica SP5 TCS 4D confocal laser scanning fluorescence microscope with a $63 \times, 1.4$ N.A. oil PlanApo objective. Twenty nuclei were scanned for each condition and the digital images were reconstructed using Volocity software (Perkin Elmer, Waltham, MA, USA). Image stacks were subjected to uniform $90 \%$ intensity thresholding along with separation of touching objects to demarcate the foci signals. This technique allowed for automatic quantification of $\gamma \mathrm{H} 2 \mathrm{AX}$ foci within the nuclear volume.

\section{Fluorescent in situ hybridization}

Touch preparations of primary thyrocytes and HTori-3 cells grown in chamber slides were subjected to 3D fixation in $4 \%$ paraformaldehyde followed by repeatable freeze-thaw cycles in liquid nitrogen (Cremer et al. 2008). RET, NCOA4, and CCDC6 probes were labeled by nick translation, hybridized, and analyzed as described previously (Gandhi et al. 2006).

\section{Statistical analysis}

The two-tailed $t$-test for independent samples was used to compare the number of $\gamma \mathrm{H} 2 \mathrm{AX}$ foci induced by irradiation and RE, distances between specific probe pairs, and rates of RET/PTC rearrangement formation in different experiments. The difference was considered statistically significant when $P$ was $<0.05$.

\section{Results}

\section{Restriction enzymes simulate IR-induced DSBs in human thyroid cells}

First, we evaluated the ability of the RE PvuII to induce DSBs at known chromosomal sites in primary cultures 
of cells (PCCs) established from normal human thyroid tissue. DSB formation was monitored by immunostaining for $\gamma \mathrm{H} 2 \mathrm{AX}$ foci, which form at DSB sites (Rogakou et al. 1998, Sedelnikova et al. 2002). We observed that the number of $\gamma \mathrm{H} 2 \mathrm{AX}$ foci generated by PvuII was increasing with the increased dose of enzyme (Fig. 1). The dose response was close to linear when the cells were electroporated in the buffer containing between 5 and 100 U PvuII. Higher doses of PvuII (250 and $500 \mathrm{U}$ ) produced very large regions of $\gamma \mathrm{H} 2 \mathrm{AX}$ staining, suggesting that foci had conglomerated. The foci induced by PvuII were diffusely distributed within the nuclear volume, which is similar to what is seen in cells treated with IR. However, in contrast to $\gamma$-radiation, which induced foci in $100 \%$ of cells, PvuII induced foci in 70-89\% of cells. Nevertheless, when only cells that had an increased number of $\gamma \mathrm{H} 2 \mathrm{AX}$ foci were scored, the number of foci induced by 25 and $100 \mathrm{U}$ of electroporated PvuII were comparable with the number of foci induced by 1 and 3 Gy of IR, respectively, which is the dose range known to produce RET/PTC rearrangements in thyroid cells in vitro (Caudill et al. 2005) and induce thyroid cancer in human populations (Ron et al. 1995, Cardis et al. 2005a,b). These data provided evidence that DSB can be induced in human cells by RE in a dosedependent manner and in quantities and distribution similar to DSB induced by IR doses known to cause carcinogenic chromosomal rearrangements.

Then, we investigated whether the kinetics of induction and repair of DSBs induced by PvuII and by $\gamma$-radiation is similar between PCC cells and immortalized HTori-3 thyroid cells. After exposure to $\gamma$-radiation, the fraction of cells with $\gamma \mathrm{H} 2 \mathrm{AX}$ foci in both types of cells was highest at the earliest time point examined (15 min post-irradiation) and declined with similar kinetics (Fig. 2A). In both cell types, the fraction of cells with induced foci declined more
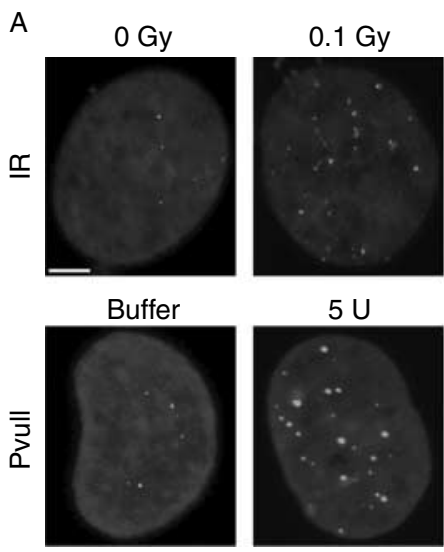

$5 \mathrm{U}$
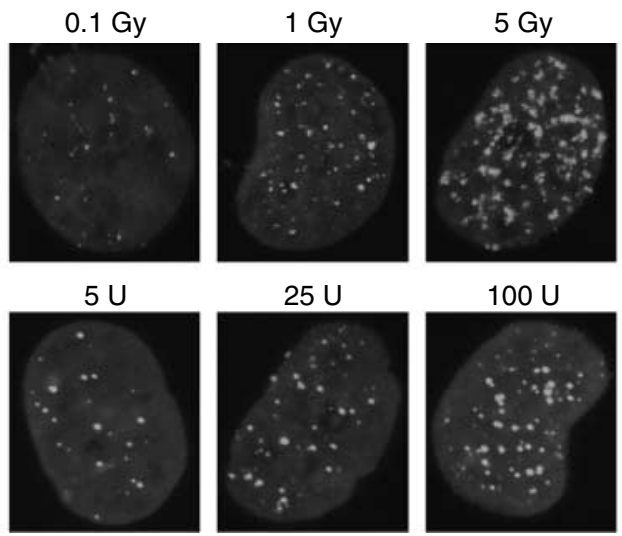

$100 \mathrm{U}$

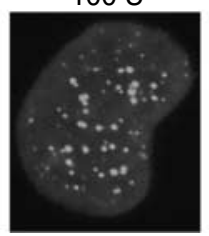

B

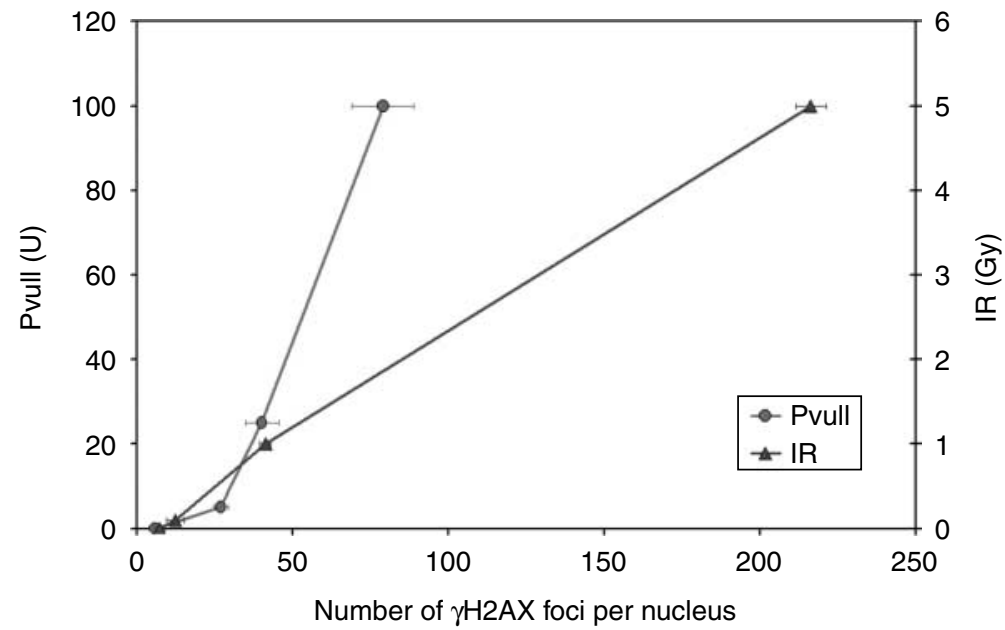

Figure 1 Comparison of DSBs induced by $\gamma$-radiation and Pvull in primary cultured thyroid cells evaluated based on $\gamma \mathrm{H} 2 \mathrm{AX}$ foci formation. (A) $\gamma \mathrm{H} 2 \mathrm{AX}$ foci distribution in cells. (B) Correlation between the number of induced $\gamma \mathrm{H} 2 \mathrm{AX}$ foci and radiation dose and dose of Pvull. 
A
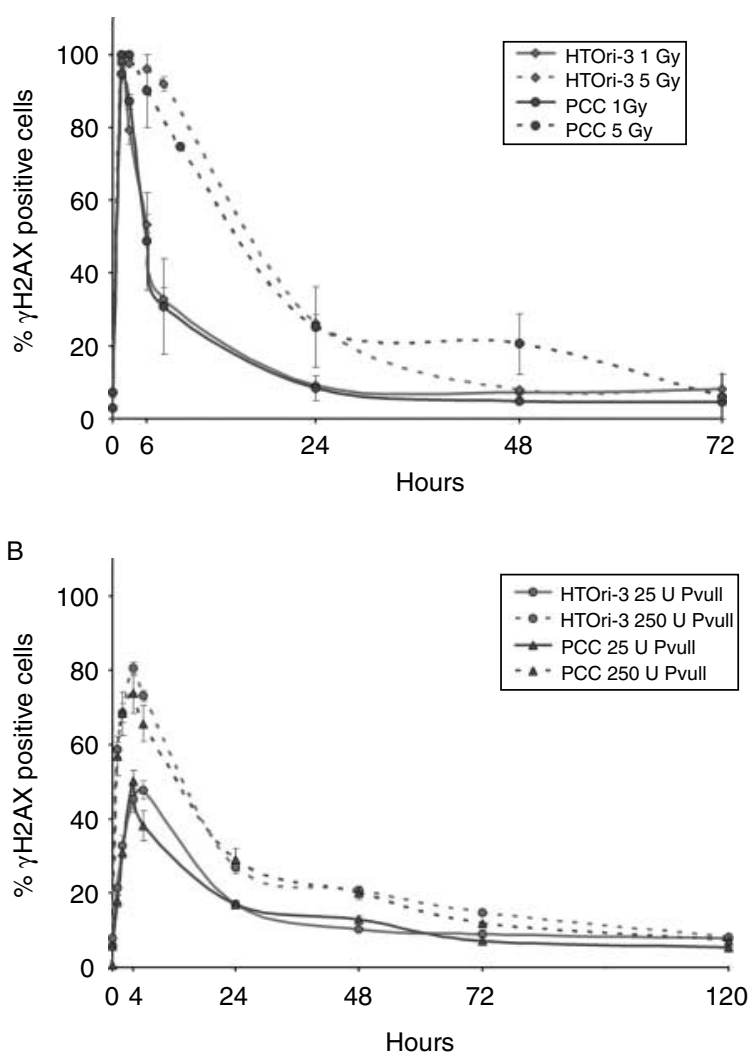

Figure 2 Kinetics of DSB repair in HTori-3 thyroid cells and primary cell cultures (PCC) induced by different doses of $\gamma$-radiation (A) and Pvull (B).

slowly in cells treated with 5 Gy compared with 1 Gy. Similar results were obtained in cells electroporated in the presence of low $(25 \mathrm{U})$ and high $(250 \mathrm{U})$ dose of PvuII, except that it took longer for cells with foci to reach its maximum and return to baseline (Fig. 2B). In both cell types, the fraction of cells with induced $\gamma \mathrm{H} 2 \mathrm{AX}$ foci was higher in cells that were electroporated in the presence of $250 \mathrm{U}$ compared with $25 \mathrm{U}$ PvuII, and this fraction declined more slowly (Fig. 2B). The slower kinetics of focus formation and dissolution after RE treatment were not surprising given the requirement for transport of the enzyme into the nucleus and the known persistence of endonuclease activity for up to $12 \mathrm{~h}$ after electroporation (Costa \& Bryant 1991), in contrast to the virtually immediate one-time induction of DSBs by IR. These results indicated that both types of cells repaired induced DSBs with similar kinetics. In addition, using 3D fluorescent in situ hybridization (FISH) analysis, we determined that HTori-3 cells, known to have three copies of intact chromosome 10 , preserve spatial proximity between the RET, NCOA4, and CCDC6 gene loci which has been previously observed in normal human thyroid cells (Nikiforova et al. 2000, Gandhi et al. 2006; Supplementary Figure 1, see section on supplementary data given at the end of this article). These findings indicate that induction of DSBs by electroporation of RE into a stable cell line (HTori-3 cells) could be used as a model to study the mechanisms of RET/PTC rearrangement that arise in human thyroid cells after exposure to IR. Moreover, HTori-3 cells provide a source of large quantity of stably dividing human thyroid cells that are required for such experiments and which cannot be obtained by culturing normal human thyroid cells.

\section{REs induced RET/PTC rearrangements with predominance of RET/PTC3 type}

The ability of restriction enzymes to induce RET/PTC rearrangements in thyroid cells was tested using HTori-3 cells and five blunt-end cutting REs: PvuII, EcoRV, NruI, ScaI, and StuI. The enzymes chosen induced DSBs in $>60 \%$ of cells at a dose that allowed more than $70 \%$ of the electroporated cells to survive. The panel of enzymes was also chosen in order to test the validity of the three different theoretical models of radiation-induced rearrangement. Consequently, the enzymes used differed with respect to their capacity to cleave the sequences that become joined in RET/PTC1 and $R E T / P T C 3$ rearrangements. In RET/PTC1, intron 11 of $R E T$ recombines with intron 1 of $C C D C 6$. In $R E T / P T C 3$, intron 11 of $R E T$ recombines with intron 7 of NCOA4. All three pertinent introns have ScaI cleavage sites, but intron 7 of NCOA4 lacks sites for PvuII and StuI, and intron 1 of CCDC6 is the only intron that has an EcoRV site (Table 1 and Fig. 3). None of the three introns have an NruI site. Therefore, if two breaks were needed (Breakage-and-Reunion theory), then ScaI would be expected to induce both RET/PTC1 and RET/PTC3 because there are sites for

Table 1 Number and characteristics of restriction enzyme digestion sites in genes participating in RET/PTC rearrangements

\begin{tabular}{lccc}
\hline & \multicolumn{2}{c}{$\begin{array}{c}\text { Number of digestion sites and distance } \\
\text { between closest restriction sites }\end{array}$} \\
\cline { 2 - 4 } Restriction & $R E T$ intron 11, & NCOA4 intron & $C C D C 6$ intron \\
enzyme & $1.8 \mathrm{~kb}$ & $7,1.7 \mathrm{~kb}$ & $1,53.4 \mathrm{~kb}$ \\
\hline Scal & $2(332 \mathrm{bp})$ & $2(1274 \mathrm{bp})$ & $9(397 \mathrm{bp})$ \\
Pvull & $3(24 \mathrm{bp})$ & 0 & $22(327 \mathrm{bp})$ \\
Stul & $4(65 \mathrm{bp})$ & 0 & $10(551 \mathrm{bp})$ \\
EcoRV & 0 & 0 & $4(3271 \mathrm{bp})$ \\
Nrul & 0 & 0 & 0
\end{tabular}

${ }^{\text {aD }}$ istance between closest restriction sites is shown in brackets. 

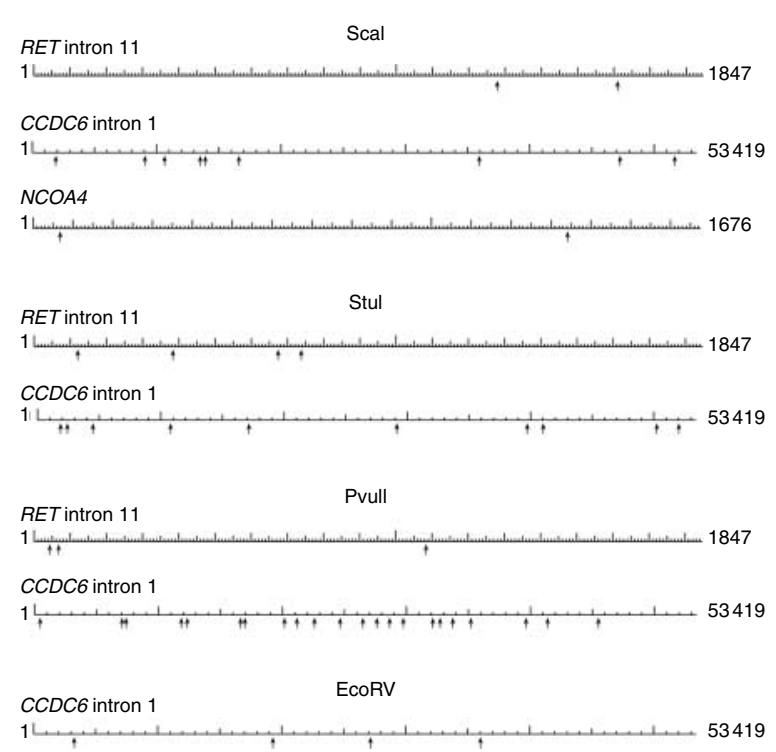

Figure 3 Restriction maps of gene regions that contain breakpoints involved in forming RET/PTC1 (RET intron 11 and CCDC6 intron 1) and RET/PTC3 (RET intron 11 and NCOA4 intron 7).

this enzyme in all three of the pertinent genes. Similarly, PvuII and StuI would induce RET/PTCl but not RET/PTC3, and EcoRV and NruI would not induce RET/PTC at all. However, if only one break were needed (the Molecular theory), then only NruI would be expected to fail to induce RET/PTC. The Exchange theory, which postulates the formation of initiation lesions that are not DSB, would seem to be not applicable to genomes damaged by restriction enzymes. Nevertheless, if NruI were to induce RET/ $P T C$, such a result would support the hypothesis of a mechanism that does not directly involve one or more DSBs in the DNA sequences that recombine.

Induction of RET/PTC rearrangements was studied by RT-PCR using the approach we previously used to study the generation of this rearrangement by $\gamma$-radiation (Fig. 4; Caudill et al. 2005). RET/PTC rearrangements were detected after electroporation with either PvuII (25 and $100 \mathrm{U}$ ) or StuI (100 and $250 \mathrm{U}$ ) (Table 2). Each enzyme produced both rearrangement types, although RET/PTC 3 was by far the most common type induced by PvuII. The rate of RET/PTCl induction by both enzymes was $0.12-0.17$ per $10^{6}$ cells, whereas the rate of RET/PTC 3 formation was $0.15-0.34$ per $10^{6}$ cells by StuI and $2.19-2.92$ by PvuII. The other three restriction enzymes tested did not induce detectable RET/PTC rearrangement. Doses of PvuII and StuI that produced RET/PTC rearrangements induced between 40 and 200 DSBs per cell, as estimated based on the number of $\gamma \mathrm{H} 2 \mathrm{AX}$ foci.
This amount of DNA damage is in the range induced by $1-5$ Gy of IR (Sedelnikova et al. 2002).

\section{Induction of RET/PTC rearrangements correlated with clustering of RE cleavage sites in one of the fusion partners}

RET/PTC was found in cells treated with either StuI or PvuII, indicating that enzymatic DNA cleavage can cause these types of rearrangements. However, RET/PTC3 rearrangements greatly predominated in cells electroporated with PvuII, despite the fact that one of the RET/PTC3 fusion partners, the PTC3 intron 7, contains no PvuII sites (Table 1 and Fig. 3). The presence of wild-type sequences of RET intron 11 and NCOA4 intron 7 in HTori-3 cells was confirmed by nucleotide sequencing, and PCR products of these intronic sequences showed patterns of digestion expected based on their restriction maps (Supplementary Figure 2, see section on supplementary data given at the end of this article). On the other hand, induction of DSB in one gene was not always sufficient to produce $R E T / P T C$ because it was not generated by either EcoRV or ScaI. These findings indicate that induction of RET/PTC was dependent on some other features of DNA damage induced by specific RE. Indeed, a unique feature of PvuII and StuI is that their sites are clustered in RET intron 11. Specifically, the intron contains two PvuII sites only 24 bp apart and

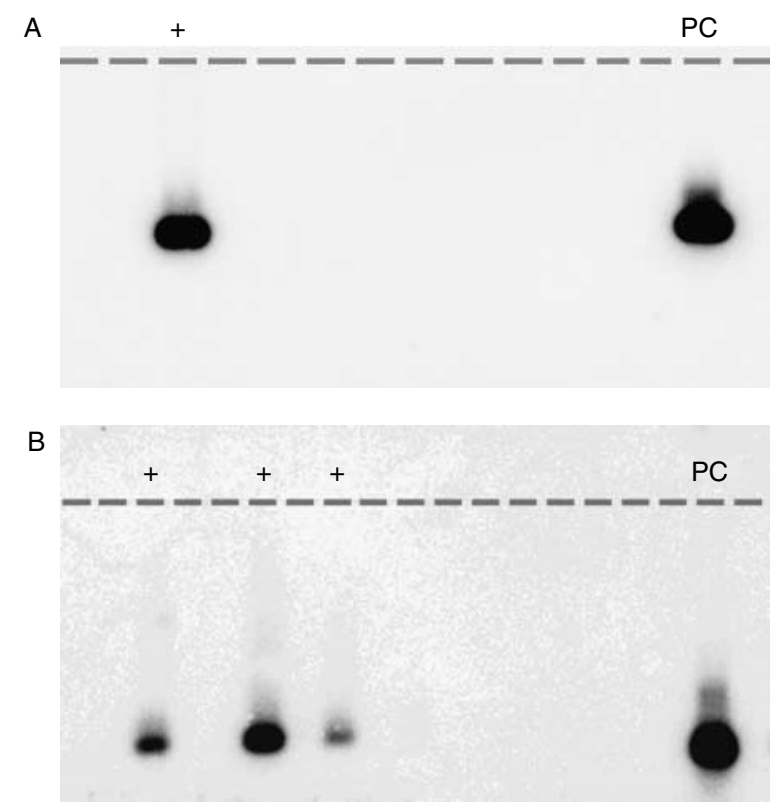

Figure 4 Examples of phosphorimages detecting samples positive for RET/PTC1 (A) and RET/PTC3 (B) rearrangements induced by $25 \mathrm{U}$ of Pvull restriction endonuclease. PC, positive control. 
Table 2 Rate of induction of RET/PTC rearrangements by restriction enzymes

\begin{tabular}{lccccc}
\hline & \multicolumn{2}{c}{$\boldsymbol{R E T / P T C 1}$} & & \multicolumn{2}{c}{$\boldsymbol{R E T / P T C 3}$} \\
\cline { 2 - 3 } \cline { 5 - 6 } $\begin{array}{l}\text { Enzyme } \\
\text { (units) }\end{array}$ & $\begin{array}{c}\text { Total } \\
\text { identified }\end{array}$ & $\begin{array}{c}\text { Rate per } \\
\mathbf{1 0}^{\mathbf{6}} \text { cells }\end{array}$ & $\begin{array}{c}\text { Total } \\
\text { identified }\end{array}$ & $\begin{array}{l}\text { Rate per } \\
\mathbf{1 0}^{\mathbf{6}} \text { cells }\end{array}$ \\
\hline Buffer only & 0 & 0 & & 0 & 0 \\
Pvull (25) & 1 & 0.12 & & 18 & 2.19 \\
Pvull (100) & 0 & 0.00 & & 13 & 2.92 \\
Stul (100) & 0 & 0.00 & & 1 & 0.15 \\
Stul (250) & 1 & 0.17 & & 2 & 0.34 \\
Scal (25) & 0 & 0 & & 0 & 0 \\
Scal (100) & 0 & 0 & & 0 & 0 \\
EcoRV (25) & 0 & 0 & & 0 & 0 \\
Nrul (100) & 0 & 0 & & 0 & 0 \\
\hline
\end{tabular}

two StuI sites separated by $65 \mathrm{bp}$ (Table 1). By contrast, relevant restriction sites of EcoRV and ScaI are $300 \mathrm{bp}$ or more apart.

\section{Discussion}

The results of this study demonstrate that carcinogenic chromosomal rearrangements can be generated in human thyroid cells as a result of DSBs caused by restriction enzymes. The predominant type of the fusion was RET/PTC3, which is characteristic of human thyroid cancer arising after exposure to I-131. Moreover, our results raise a possibility that RET/PTC can be formed in human thyroid cells as a result of a complex DSB produced in one of the genes participating in the fusion.

The preferential formation of RET/PTC3 after electroporation of $\mathrm{RE}$ found in this study was unexpected because RET/PTCl is a predominant type of the rearrangement in most human populations and in experimental exposures to IR (Bounacer et al. 1997, Collins et al. 2002, Hamatani et al. 2008). The notable exception is a population of individuals exposed predominantly to radioiodines as a result of the Chernobyl accident who developed thyroid cancer during the first 10 years after exposure, where RET/ PTC3 was much more common than RET/PTC1 (Nikiforov et al. 1997, Smida et al. 1999, Thomas et al. 1999, Rabes et al. 2000). The reason for RET/ $P T C 3$ prevalence in this population was not clear, and this was believed to represent a sporadic phenomenon characteristic of this population only. However, the results of this study indicate that the same type of human thyroid cells (HTori-3) form predominantly RET/PTC 3 after induction of DSBs by RE, and RET/ PTC1 after exposure to $\gamma$-radiation (Caudill et al. 2005). This suggests that the choice of rearrangement type is not random and not cell-type specific but rather is a manifestation of the underlying mechanisms, which can be further studied using a model established in this study.

One possible explanation for the difference between the predominance of RET/PTC3 over RET/PTCl in human populations and after RE electroporation compared with $\gamma$-radiation may be related to the mode of DSB generation. Both I-131 (half-life of 8.04 days) and PvuII endonuclease activities (known to persist for at least $12 \mathrm{~h}$ after electroporation (Costa \& Bryant 1991)) result in continuous induction of DSBs, in contrast to a one-time action of $\gamma$-radiation.

RET/PTC events in this study were detected after inducing DNA damage with two out of five REs used. It is unlikely that the failure of some REs to induce $R E T / P T C$ reflects failure to cause DSB because all the enzymes generated a similar number of $\gamma \mathrm{H} 2 \mathrm{AX}$ foci. It is possible that the ability to induce RET/PTC depends on the location and characteristics of the induced breaks. RET intron 11 contains a pair of PvuII sites and a pair of StuI sites, the two enzymes that induced RET/PTC. Cleaving at both sites would cause a small deletion and a DSB. Perhaps such damage is less prone to repair and is therefore more likely to elicit a different repair outcome, such as RET/PTC. Incidentally, PvuII has two restriction sites located on a shorter distance than StuI, and it was approximately tenfold stronger as an inducer of RET/PTC3. In is interesting to note that both $\gamma$-radiation and I-131 are known to produce clustered breaks and breaks that cannot be ligated because they lack the required 5'-phosphate and/or 3'hydroxyl group (Goodhead 1994, Sutherland et al. 2000, 2002). The I-131 isotope, which emits both $\gamma$-radiation and $\beta$-particles, has an even higher potential for producing complex DNA damage. The charged particles have more complex track structure and denser energy deposition than $\gamma$-radiation, with higher chance of inducing DSBs and clustered DNA damage (Goodhead 1994, Hada \& Georgakilas 2008). In thyroid cells, I-131 induces DSBs detectable as $\gamma \mathrm{H} 2 \mathrm{AX}$ or 53BP1 foci (Hershman et al. 2011), as well as clustered DNA damage detected by Comet assay (Grzesiuk et al. 2006). Taken together, these data and results of our study raise at least a theoretical possibility that complex DSB in one gene is sufficient to initiate the generation of RET/PTC rearrangement in thyroid cells. This would support a one-hit mechanism postulated by the Molecular theory (Chadwick \& Leenhouts 1978, Goodhead et al. 1993).

Alternately, it remains possible that the formation of RET/PTC3 occurred via two breaks, the first being formed by PvuII cutting at its canonical recognition 
sites and the second being formed in the NCOA4 gene by nonspecific cleavage. In vitro, under artificial conditions, PvuII can cleave DNA at sites that match only five of the six bases in the canonical PvuII cleavage site (Nasri \& Thomas 1987, Robinson \& Sligar 1995). However, such star activity has not been observed in vivo (Nastri et al. 1997, Simoncsits et al. 2001), and inspection of RET/PTC3 junctions found no evidence of breaks made by PvuII star activity. Furthermore, nonspecific cutting has not been shown for StuI. Therefore, the data do not support nonspecific cleavage by any known capability of PvuII.

In summary, in this study, we established a model of DSBs induced by various REs in human thyroid cells and report for the first time the formation of a carcinogenic chromosomal rearrangement after RE electroporation. The results obtained using this model suggest that complex DSB produced in one of the fusion partners may be sufficient for the formation of RET/PTC in thyroid cells. Moreover, this model can be used for further studies of radiation carcinogenesis in human thyroid cells, particularly in light of a similarity of $R E T / P T C$ types induced by $\mathrm{RE}$ and by radioiodine.

\section{Supplementary data}

This is linked to the online version of the paper at http://dx. doi.org/10.1530/ERC-11-0314.

\section{Declaration of interest}

The authors declare that there is no conflict of interest that could be perceived as prejudicing the impartiality of the research reported.

\section{Funding}

This work was supported by a grant from the National Institutes of Health (R01 CA88041) to Y E Nikiforov.

\section{Acknowledgements}

The authors thank William F Morgan for guidance with setting up cell electroporation experiments and Li Chen and Svetlana Fischer for technical assistance.

\section{References}

Ager DD, Phillips JW, Columna EA, Winegar RA \& Morgan WF 1991 Analysis of restriction enzyme-induced DNA double-strand breaks in Chinese hamster ovary cells by pulsed-field gel electrophoresis: implications for chromosome damage. Radiation Research 128 150-156. (doi:10.2307/3578132)
Bongarzone I, Butti MG, Fugazzola L, Pacini F, Pinchera A, Vorontsova TV, Demidchik EP \& Pierotti MA 1997 Comparison of the breakpoint regions of ELE1 and RET genes involved in the generation of RET/PTC3 oncogene in sporadic and in radiation-associated papillary thyroid carcinomas. Genomics 42 252-259. (doi:10.1006/geno. 1997.4685)

Bounacer A, Wicker R, Caillou B, Cailleux AF, Sarasin A, Schlumberger M \& Suárez HG 1997 High prevalence of activating ret proto-oncogene rearrangements, in thyroid tumors from patients who had received external radiation. Oncogene 15 1263-1273. (doi:10.1038/sj.onc.1200206)

Bryant PE 1984 Enzymatic restriction of mammalian cell DNA using Pvu II and Bam H1: evidence for the doublestrand break origin of chromosomal aberrations. International Journal of Radiation Biology and Related Studies in Physics, Chemistry, and Medicine 46 57-65. (doi:10.1080/09553008414551061)

Bryant PE 1988 Use of restriction endonucleases to study relationships between DNA double-strand breaks, chromosomal aberrations and other end-points in mammalian cells. International Journal of Radiation Biology 54 869-890. (doi:10.1080/09553008814552291)

Bryant PE \& Riches AC 1989 Oncogenic transformation of murine $\mathrm{C} 3 \mathrm{H} 10 \mathrm{~T} 1 / 2$ cells resulting from DNA doublestrand breaks induced by a restriction endonuclease. British Journal of Cancer 60 852-854. (doi:10.1038/bjc. 1989.378)

Cardis E, Kesminiene A, Ivanov V, Malakhova I, Shibata Y, Khrouch V, Drozdovitch V, Maceika E, Zvonova I, Vlassov O et al. 2005a Risk of thyroid cancer after exposure to ${ }^{131} \mathrm{I}$ in childhood. Journal of the National Cancer Institute 97 724-732. (doi:10.1093/jnci/dji129)

Cardis E, Vrijheid M, Blettner M, Gilbert E, Hakama M, Hill C, Howe G, Kaldor J, Muirhead CR, Schubauer-Berigan M et al. 2005b Risk of cancer after low doses of ionising radiation: retrospective cohort study in 15 countries. $B M J$ 331 77. (doi:10.1136/bmj.38499.599861.E0)

Carney JP \& Morgan WF 1999 Induction of DNA doublestrand breaks by electroporation of restriction enzymes into mammalian cells. Methods in Molecular Biology 113 465-471.

Caudill CM, Zhu Z, Ciampi R, Stringer JR \& Nikiforov YE 2005 Dose-dependent generation of RET/PTC in human thyroid cells after in vitro exposure to gamma-radiation: a model of carcinogenic chromosomal rearrangement induced by ionizing radiation. Journal of Clinical Endocrinology and Metabolism 90 2364-2369. (doi:10. 1210/jc.2004-1811)

Chadwick KH \& Leenhouts HP 1978 The rejoining of DNA double-strand breaks and a model for the formation of chromosomal rearrangements. International Journal of Radiation Biology and Related Studies in Physics, Chemistry, and Medicine 33 517-529. (doi:10.1080/ 09553007814550431)

Ciampi R, Knauf JA, Kerler R, Gandhi M, Zhu Z, Nikiforova MN, Rabes HM, Fagin JA \& Nikiforov YE 
2005 Oncogenic AKAP9-BRAF fusion is a novel mechanism of MAPK pathway activation in thyroid cancer. Journal of Clinical Investigation 115 94-101. (doi:10.1172/JCI200523237)

Collins BJ, Chiappetta G, Schneider AB, Santoro M, Pentimalli F, Fogelfeld L, Gierlowski T, Shore-Freedman E, Jaffe G \& Fusco A 2002 RET expression in papillary thyroid cancer from patients irradiated in childhood for benign conditions. Journal of Clinical Endocrinology and Metabolism 87 3941-3946. (doi:10.1210/jc.87.8.3941)

Costa ND \& Bryant PE 1991 Differences in accumulation of blunt- and cohesive-ended double-strand breaks generated by restriction endonucleases in electroporated $\mathrm{CHO}$ cells. Mutation Research 254 239-246.

Cremer M, Grasser F, Lanctôt C, Müller S, Neusser M, Zinner R, Solovei I \& Cremer T 2008 Multicolor 3D fluorescence in situ hybridization for imaging interphase chromosomes. Methods in Molecular Biology 463 205-239.

Edwards AA 2002 Modelling radiation-induced chromosome aberrations. International Journal of Radiation Biology 78 551-558. (doi:10.1080/09553000210132315)

Gandhi M, Medvedovic M, Stringer JR \& Nikiforov YE 2006 Interphase chromosome folding determines spatial proximity of genes participating in carcinogenic RET/PTC rearrangements. Oncogene 25 2360-2366. (doi:10.1038/sj.onc.1209268)

Gandhi M, Evdokimova V \& Nikiforov YE 2010 Mechanisms of chromosomal rearrangements in solid tumors: the model of papillary thyroid carcinoma. Molecular and Cellular Endocrinology 321 36-43. (doi:10.1016/j.mce.2009.09.013)

Goodhead DT 1994 Initial events in the cellular effects of ionizing radiations: clustered damage in DNA. International Journal of Radiation Biology 65 7-17. (doi:10.1080/09553009414550021)

Goodhead DT, Thacker J \& Cox R 1993 Weiss Lecture. Effects of radiations of different qualities on cells: molecular mechanisms of damage and repair. International Journal of Radiation Biology 63 543-556. (doi:10.1080/09553009314450721)

Grieco M, Santoro M, Berlingieri MT, Melillo RM, Donghi R, Bongarzone I, Pierotti MA, Della Porta G, Fusco A \& Vecchio G 1990 PTC is a novel rearranged form of the ret proto-oncogene and is frequently detected in vivo in human thyroid papillary carcinomas. Cell $60557-563$. (doi:10.1016/0092-8674(90)90659-3)

Grzesiuk W, Nieminuszczy J, Kruszewski M, Iwanienko T, Plazinska M, Bogdanska M, Bar-Andziak E, Królicki L \& Grzesiuk E 2006 DNA damage and its repair in lymphocytes and thyroid nodule cells during radioiodine therapy in patients with hyperthyroidism. Journal of Molecular Endocrinology 37 527-532. (doi:10.1677/jme. 1.02174)

Hada M \& Georgakilas AG 2008 Formation of clustered DNA damage after high-LET irradiation: a review. Journal of Radiation Research 49 203-210. (doi:10.1269/ jrr.07123)
Hamatani K, Eguchi H, Ito R, Mukai M, Takahashi K, Taga M, Imai K, Cologne J, Soda M, Arihiro K et al. 2008 RET/PTC rearrangements preferentially occurred in papillary thyroid cancer among atomic bomb survivors exposed to high radiation dose. Cancer Research 68 7176-7182. (doi:10.1158/0008-5472.CAN-08-0293)

Hershman JM, Okunyan A, Rivina Y, Cannon S \& Hogen V 2011 Prevention of DNA double-strand breaks induced by radioiodide-(131)I in FRTL-5 thyroid cells. Endocrinology 152 1130-1135. (doi:10.1210/en.2010-1163)

Hlatky L, Sachs RK, Vazquez M \& Cornforth MN 2002 Radiation-induced chromosome aberrations: insights gained from biophysical modeling. Bioessays $\mathbf{2 4}$ 714-723. (doi:10.1002/bies.10126)

Huang L, Snyder AR \& Morgan WF 2003 Radiation-induced genomic instability and its implications for radiation carcinogenesis. Oncogene 22 5848-5854. (doi:10.1038/sj. onc.1206697)

Ito T, Seyama T, Iwamoto KS, Hayashi T, Mizuno T, Tsuyama N, Dohi K, Nakamura N \& Akiyama M 1993 In vitro irradiation is able to cause RET oncogene rearrangement. Cancer Research 53 2940-2943.

Klugbauer S, Pfeiffer P, Gassenhuber H, Beimfohr C \& Rabes HM 2001 RET rearrangements in radiationinduced papillary thyroid carcinomas: high prevalence of topoisomerase I sites at breakpoints and microhomologymediated end joining in ELE1 and RET chimeric genes. Genomics 73 149-160. (doi:10.1006/geno.2000.6434)

Lemoine NR, Mayall ES, Jones T, Sheer D, McDermid S, Kendall-Taylor P \& Wynford-Thomas D 1989 Characterisation of human thyroid epithelial cells immortalised in vitro by simian virus 40 DNA transfection. British Journal of Cancer 60 897-903. (doi:10.1038/ bjc.1989.387)

Little JB 2003 Genomic instability and radiation. Journal of Radiological Protection 23 173-181. (doi:10.1088/09524746/23/2/304)

Little JB, Nagasawa H, Li GC \& Chen DJ 2003 Involvement of the nonhomologous end joining DNA repair pathway in the bystander effect for chromosomal aberrations. Radiation Research 159 262-267. (doi:10.1667/00337587(2003)159[0262:IOTNEJ]2.0.CO;2)

Ludwików G, Xiao Y, Hoebe RA, Franken NA, Darroudi F, Stap J, Van Oven CH, Van Noorden CJ \& Aten JA 2002 Induction of chromosome aberrations in unirradiated chromatin after partial irradiation of a cell nucleus. International Journal of Radiation Biology 78 239-247. (doi:10.1080/09553000110110086)

Mizuno T, Iwamoto KS, Kyoizumi S, Nagamura H, Shinohara T, Koyama K, Seyama T \& Hamatani K 2000 Preferential induction of RET/PTC1 rearrangement by X-ray irradiation. Oncogene 19 438-443. (doi:10.1038/sj. onc.1203343)

Morgan WF, Hartmann A, Limoli CL, Nagar S \& Ponnaiya B 2002 Bystander effects in radiation-induced genomic instability. Mutation Research 504 91-100. (doi:10.1016/ S0027-5107(02)00083-0) 
Nasri M \& Thomas D 1987 Alteration of the specificity of PvuII restriction endonuclease. Nucleic Acids Research 15 7677-7687. (doi:10.1093/nar/15.19.7677)

Nastri HG, Evans PD, Walker IH \& Riggs PD 1997 Catalytic and DNA binding properties of PvuII restriction endonuclease mutants. Journal of Biological Chemistry 272 25761-25767. (doi:10.1074/jbc.272.41.25761)

Nikiforov YE, Rowland JM, Bove KE, Monforte-Munoz H \& Fagin JA 1997 Distinct pattern of ret oncogene rearrangements in morphological variants of radiationinduced and sporadic thyroid papillary carcinomas in children. Cancer Research 57 1690-1694.

Nikiforov YE, Koshoffer A, Nikiforova M, Stringer J \& Fagin JA 1999 Chromosomal breakpoint positions suggest a direct role for radiation in inducing illegitimate recombination between the ELE1 and RET genes in radiation-induced thyroid carcinomas. Oncogene 18 6330-6334. (doi:10.1038/sj.onc.1203019)

Nikiforova MN, Stringer JR, Blough R, Medvedovic M, Fagin JA \& Nikiforov YE 2000 Proximity of chromosomal loci that participate in radiation-induced rearrangements in human cells. Science 290 138-141. (doi:10.1126/science.290.5489.138)

Obe G, Johannes C \& Schulte-Frohlinde D 1992 DNA double-strand breaks induced by sparsely ionizing radiation and endonucleases as critical lesions for cell death, chromosomal aberrations, mutations and oncogenic transformation. Mutagenesis 7 3-12. (doi:10.1093/ mutage/7.1.3)

Rabes HM, Demidchik EP, Sidorow JD, Lengfelder E, Beimfohr C, Hoelzel D \& Klugbauer S 2000 Pattern of radiation-induced RET and NTRK1 rearrangements in 191 post-chernobyl papillary thyroid carcinomas: biological, phenotypic, and clinical implications. Clinical Cancer Research 6 1093-1103.

Revell SH 1975 Proceedings: a speculation about observed differences in X-ray sensitivities of euploid and aneuploid mammalian cells. British Journal of Radiology 48 416-417.

Robinson CR \& Sligar SG 1995 Heterogeneity in molecular recognition by restriction endonucleases: osmotic and hydrostatic pressure effects on BamHI, Pvu II, and EcoRV specificity. PNAS 92 3444-3448. (doi:10.1073/pnas.92.8. 3444)

Rogakou EP, Pilch DR, Orr AH, Ivanova VS \& Bonner WM 1998 DNA double-stranded breaks induce histone H2AX phosphorylation on serine 139. Journal of Biological Chemistry 273 5858-5868. (doi:10.1074/jbc.273.10.5858)

Ron E, Lubin JH, Shore RE, Mabuchi K, Modan B, Pottern LM, Schneider AB, Tucker MA \& Boice JD Jr 1995 Thyroid cancer after exposure to external radiation: a pooled analysis of seven studies. Radiation Research 141 259-277. (doi:10.2307/3579003)

Rothkamm K, Kuhne M, Jeggo PA \& Lobrich M 2001 Radiation-induced genomic rearrangements formed by nonhomologous end-joining of DNA double-strand breaks. Cancer Research 61 3886-3893.
Santoro M, Dathan NA, Berlingieri MT, Bongarzone I, Paulin C, Grieco M, Pierotti MA, Vecchio G \& Fusco A 1994 Molecular characterization of RET/PTC3; a novel rearranged version of the RETproto-oncogene in a human thyroid papillary carcinoma. Oncogene $\mathbf{9}$ 509-516.

Savage JR 1998 A brief survey of aberration origin theories. Mutation Research 404 139-147. (doi:10.1016/S00275107(98)00107-9)

Schlumberger M, Cailleux AF, Suarez HG \& de Vathaire F 1999 Irradiation and second cancers. The thyroid as a case in point. Comptes Rendus de l'Académie des Sciences. Series III, Sciences de la Vie 322 205-213. (doi:10.1016/ S0764-4469(99)80045-6)

Schneider AB 1990 Radiation-induced thyroid tumors. Endocrinology and Metabolism Clinics of North America 19 495-508.

Sedelnikova OA, Rogakou EP, Panyutin IG \& Bonner WM 2002 Quantitative detection of (125)IdU-induced DNA double-strand breaks with gamma-H2AX antibody. Radiation Research 158 486-492. (doi:10.1667/00337587(2002)158[0486:QDOIID]2.0.CO;2)

Simoncsits A, Tjornhammar ML, Rasko T, Kiss A \& Pongor S 2001 Covalent joining of the subunits of a homodimeric type II restriction endonuclease: single-chain PvuII endonuclease. Journal of Molecular Biology 309 89-97. (doi:10.1006/jmbi.2001.4651)

Smida J, Salassidis K, Hieber L, Zitzelsberger H, Kellerer AM, Demidchik EP, Negele T, Spelsberg F, Lengfelder E, Werner M et al. 1999 Distinct frequency of ret rearrangements in papillary thyroid carcinomas of children and adults from Belarus. International Journal of Cancer 80 32-38. (doi:10.1002/(SICI)1097-0215(19990105)80:1<32::AIDIJC7 > 3.0.CO;2-L)

Sutherland BM, Bennett PV, Sidorkina O \& Laval J 2000 Clustered DNA damages induced in isolated DNA and in human cells by low doses of ionizing radiation. PNAS 97 103-108. (doi:10.1073/pnas.97.1.103)

Sutherland BM, Bennett PV, Sutherland JC \& Laval J 2002 Clustered DNA damages induced by x rays in human cells. Radiation Research 157 611-616. (doi:10.1667/ 0033-7587(2002)157[0611:CDDIBX]2.0.CO;2)

Suzuki K, Okada H, Yamauchi M, Oka Y, Kodama S \& Watanabe M 2006 Qualitative and quantitative analysis of phosphorylated ATM foci induced by low-dose ionizing radiation. Radiation Research 165 499-504. (doi:10. 1667/RR3542.1)

Thomas GA, Bunnell H, Cook HA, Williams ED, Nerovnya A, Cherstvoy ED, Tronko ND, Bogdanova TI, Chiappetta G, Viglietto G et al. 1999 High prevalence of RET/PTC rearrangements in Ukrainian and Belarussian post-Chernobyl thyroid papillary carcinomas: a strong correlation between RET/PTC3 and the solid-follicular variant. Journal of Clinical Endocrinology and Metabolism 84 4232-4238. (doi:10.1210/jc.84.11.4232) 
Tuttle RM \& Becker DV 2000 The Chernobyl accident and its consequences: update at the millennium. Seminars in Nuclear Medicine 30 133-140. (doi:10.1053/nm.2000.5412)

Winegar RA, Phillips JW, Youngblom JH \& Morgan WF 1989 Cell electroporation is a highly efficient method for introducing restriction endonucleases into cells. Mutation Research 225 49-53. (doi:10.1016/0165-7992(89)90032-8)

Winegar RA, Lutze LH, Rufer JT \& Morgan WF 1992 Spectrum of mutations produced by specific types of restriction enzyme-induced double-strand breaks. Mutagenesis 7 439-445. (doi:10.1093/mutage/7.6.439)
Yates BL \& Morgan WF 1993 Nonhomologous DNA end rejoining in chromosomal aberration formation. Mutation Research 285 53-60. (doi:10.1016/00275107(93)90051-G)

Received in final form 13 January 2012

Accepted 9 February 2012

Made available online as an Accepted Preprint 9 February 2012 